\title{
Compartmental Analysis of Calcium Metabolism in Very-Low-Birth-Weight Infants ${ }^{1}$
}

\author{
STEVEN A. ABRAMS, RICHARD J. SCHANLER, ALFRED L. YERGEY, \\ NANCY E. VIEIRA, AND FELIX BRONNER
}

Department of Pediatrics, United States Department of Agriculture/Agricultural Research Senvice Children's Nutrition Research Center, Baylor College of Medicine and Texas Children's Hospital, Houston, Texas 77030 [S.A.A., R.J.S.]; Laboratony of Theoretical and Physical Biology, National Institute of Child Health and Human Development/National Institutes of Health, Bethesda, Maryland 20892 [A.L.Y., N.E.V.]; and Department of BioStructure and Function, University of Connecticut Health Center, Farmington, Connecticut 06030 [F.B.]

The calcium metabolism of 13 very-low-birth-weight infants fed a high-calcium diet was evaluated by means of stable isotope kinetic and balance studies. The studies used orally and i.v. administered stable isotopes, and the kinetic data were evaluated with the aid of a sequential, threecompartment model. The infants (postmenstrual age $33 \pm 1$ wk, weight $1.34 \pm 0.03 \mathrm{~kg}$ ) had higher bone calcium deposition rates $\left(160 \pm 7 \mathrm{mg} \cdot \mathrm{kg}^{-1} \cdot \mathrm{d}^{-1}\right.$ or $4.00 \pm 0.18$ $\left.\mathrm{mmol} \cdot \mathrm{kg}^{-1} \cdot \mathrm{d}^{-1}\right)$ than those previously reported for either older children or adults. Furthermore, when analyzed as a function of net calcium absorption, bone calcium deposition rates increased markedly and significantly as net calcium absorption increased $(r=0.70, p<0.01)$, whereas in older individuals, bone calcium deposition is a relatively invariant function of absorption. A relatively smaller response of bone calcium removal to calcium absorption was found for the very-low-birth-weight infants in this study $(r=-0.39, p=$ 0.18 ), whereas in adults, bone calcium removal constitutes the major regulatory response. It is suggested that the calcium kinetic results in the very-low-birth-weight infants reflect the high rate of bone growth typical of the third trimester of gestation. (Pediatr Res 36: 424-428, 1994)

Abbreviations
$\mathbf{V}_{\text {a }}$, true calcium absorption rate
$\mathbf{V}_{\text {endo, endogenous fecal calcium excretion rate }}$
$\mathbf{V}_{\mathrm{u}}$, urinary calcium excretion rate
$\mathrm{S}_{\mathbf{b}}$, net calcium absorption $\left(\mathrm{V}_{\mathrm{a}}-\mathrm{V}_{\text {endo }}\right)$ rate
$\mathbf{V o}^{+}$, bone calcium deposition rate
$\mathbf{V}_{\text {bal }}$, calcium retention (balance) rate $\left(\mathrm{S}_{\mathrm{i}}-\mathrm{V}_{\mathrm{u}}\right)$
VLBW, very low birth weight $(<1500 \mathrm{~g})$
APA, serum alkaline phosphatase activity

cium metabolism. Although the form of the model chosen will affect the precise numerical values for given parameters, fundamental relationships and characteristics including the bone calcium deposition and resorption rates are independent of model configuration $(2,6)$.

The application of compartmental models to the study of calcium metabolism in small infants poses significant problems $(11,12)$. Blood sampling must be minimized in infants and complete fecal and urine collections of adequate length are difficult to obtain. Because radioactive isotopes cannot ethically be used in small infants, stable isotopes must be used at much greater expense.

These limitations notwithstanding, we have assessed calcium metabolism in 13 VLBW infants using a dual isotope approach. The infants were studied at a postnatal age at which, if they had remained in utero, maximum bone growth and calcification would have been expected to occur (13).

It was of special interest to determine whether the calcium regulatory mechanisms that have been described for 
older individuals and other mammals $(4-6,8-10)$ also operate in the VLBW infant. Because of the rapid growth of these infants, we hypothesized that bone calcium deposition might play a greater regulatory role in the calcium metabolism of VLBW infants than in that of older persons.

\section{METHODS}

Subjects. Thirteen premature infants (mean birth weight, $0.97 \pm 0.04 \mathrm{~kg}$; mean gestational age, $28 \pm 1 \mathrm{wk}$ ) were studied. They were fed either their mothers' milk, fortified with a commercially available powdered human milk fortifier, or a high-mineral-containing formula designed for premature infants. All subjects were studied during their hospitalization in the nurseries of Texas Children's Hospital.

The clinical care of the infants was similar to that of low-birth-weight infants described in previous reports (14-16). All subjects were healthy and free of chronic respiratory illness and did not require diuretic therapy. Studies were approved by the institutional review boards for human research at Baylor College of Medicine and Texas Children's Hospital and informed written consent was obtained from the parents before the infants were enrolled in the study.

Isotopic studies. Details of the isotope preparation and administration have previously been reported $(14,16)$. In brief, $18 \mathrm{~h}$ before the beginning of the study, one half volume of a single feeding was mixed with ${ }^{44} \mathrm{Ca}(0.8 \mathrm{mg} / \mathrm{kg}$, $0.0182 \mathrm{mmol} / \mathrm{kg}$ ) and refrigerated until the study began. The next morning, the infants were given ${ }^{46} \mathrm{Ca}(0.010$ $\mathrm{mg} / \mathrm{kg}, 0.00022 \mathrm{mmol} / \mathrm{kg}$ ) i.v. over 3-5 min. The premixed feeding with the added ${ }^{44} \mathrm{Ca}$ was then fed orally or via an orogastric tube. The remainder of the feeding was given with the same syringe and feeding tube or bottle. Samples of the feeding and of any residual milk were analyzed for total calcium and calcium isotope ratios.

At 6 and $10 \mathrm{~min}$ after completion of the isotope infusion, blood samples were obtained by venipuncture and the serum was analyzed for isotope ratio measurements. Total serum calcium was also measured on the sample collected at $6 \mathrm{~min}$. The infants were then placed on a metabolic bed for the continuous collection of urine in 6-h pools for $72 \mathrm{~h}$. At that point, the infants were removed from the metabolic bed and three random urine samples were collected daily for the next $3 \mathrm{~d}$. Feces were collected in plastic bags that were attached to the buttocks for a total of $120 \mathrm{~h}$ after isotope administration. Each stool was analyzed separately. Milk intake was determined from samples obtained from tared feeding syringes or bottles.

Total serum calcium was measured once or twice weekly in all study subjects during their hospitalization. These values differed very little from those obtained at the time of the balance study. In no case did the total serum calcium value determined during the week before or after the balance study differ from that obtained in the balance study by more than $0.05 \mathrm{mmol} / \mathrm{L}$.
Isotope preparation and analysis. Solutions of ${ }^{46} \mathrm{Ca}$ and ${ }^{44} \mathrm{Ca}$ were prepared by the pharmacy at the National Institutes of Health (Bethesda, MD) and tested for pyrogenicity and sterility before use. The calcium content of urine and the ashed fecal samples was measured by atomic absorption spectrophotometry.

Isotopic enrichment was determined using a magnetic sector Finnigan MAT 261 thermal ionization mass spectrometer (Bremen, Germany). Details of the mass spectrometric methods have previously been described (1618). Precision of measurements was $0.1-0.2 \%$ for each isotope ratio measured.

Calculations and modeling. The compartmental model for calcium kinetics used here (Fig. 1) was similar to that described by Neer et al. (1). Because of the limited number of blood samples that were obtained during the initial period after tracer infusion, our model is based on three sequential compartments, corresponding to the last three compartments of the four-compartment model used in adults. Our approach is similar to that used by Moore et al. (12) in two former premature infants, except that we used a sequential rather than a branched model.

$\mathrm{V}_{\mathrm{a}}$ was calculated from the fraction absorbed multiplied by the daily calcium intake. Fractional absorption was calculated from the ratio of the oral to the i.v. tracer dose recovered in the urine during the first $24 \mathrm{~h}$ after tracer administration $(17,19,20)$.

$\mathrm{V}_{\text {endo }}$ was determined as previously described from the relative recovery of ${ }^{46} \mathrm{Ca}$ in the feces and the urine and total urinary calcium excretion $(14,20)$.

$\mathrm{S}_{\mathrm{i}}$, i.e. the difference between intake and fecal calcium output, equals the difference between $\mathrm{V}_{\mathrm{a}}$ and $\mathrm{V}_{\text {endo }}$. Because serum calcium is tightly regulated in healthy subjects, including premature infants after the second week of life, $\mathrm{S}_{\mathrm{i}}$ may be considered as "disturbing" signal (input) for the serum, regulated so as to maintain its calcium concentration constant. Regulation is effected by bone calcium deposition and removal, as well as by calcium excretion $(5,8,9)$.

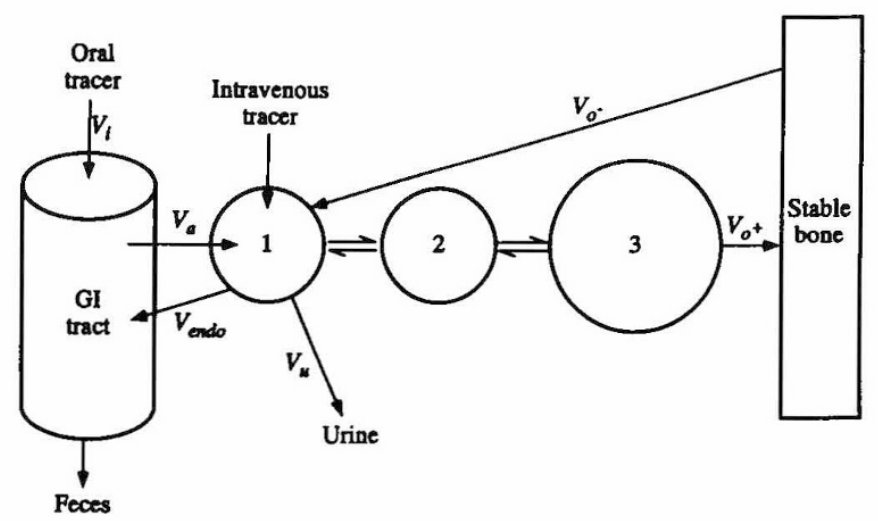

Figure 1. Multicompartmental model of calcium metabolism. Calcium is absorbed into a central compartment $(1)$ and then transferred to deep bone via two intermediate compartments. The exchangeable pool consists of compartments 1,2 , and 3 . Bone resorption $\left(\mathrm{Vo}^{-}\right)$leads to calcium return into the central compartment. 
Compartmental modeling of the data was performed with the aid of the Simulation Analysis And Modeling (SAAM) program. Details of this program and its application to neonatal calcium metabolism have been described (12). Fractional standard deviations of the parameters fitted by the SAAM program were determined for each subject and generally accounted for $5-10 \%$ for each parameter. All data are presented as the mean \pm SEM.

\section{RESULTS}

The mean weight of the infants at the start of the isotope study was $1.34 \pm 0.03 \mathrm{~kg}$; their mean age was 34 $\pm 3 \mathrm{~d}$. This led to a mean postmenstrual age of $33 \pm 1 \mathrm{wk}$. Birth weight, gestational age, body weight at study, and age at study were similar between infants fed human milk $(n=7)$ and those fed formula $(n=6)$. Body weight gain during the study averaged $23 \pm 3 \mathrm{~g} \cdot \mathrm{kg}^{-1} \cdot \mathrm{d}^{-1}$, representing a mean daily weight increase of $1.7 \%$. The average values for the parameters of calcium balance and kinetics for the 13 study subjects are summarized in Table 1 . The parameters of absorption, $V_{\text {endo }}$ and $V_{\text {bal }}$, were not significantly different between infants fed human milk and those fed formula. Calcium intake was not correlated to $V_{\text {endo }}$ or $V_{u}$, although the range of intakes was small.

Total serum calcium did not significantly vary with $S_{i}$ $(r=0.31, p=0.30)$. This indicates that, in VLBW infants receiving complete enteral nutrition, total serum calcium remained constant despite an increase in $S_{i}$ from 20 to 120 $\mathrm{mg} \cdot \mathrm{kg}^{-1} \cdot \mathrm{d}^{-1}\left(0.5\right.$ to $\left.3 \mathrm{mmol} \cdot \mathrm{kg}^{-1} \cdot \mathrm{d}^{-1}\right)$.

$\mathrm{V}_{\mathrm{u}}$ did not change with increasing $\mathrm{S}_{\mathrm{i}}$. This indicates that $V_{u}$ varied only slightly and not significantly with calcium intake and absorption over the range studied (Fig. 2). Similarly, there was no significant relationship between $\mathrm{V}_{\mathrm{a}}$ and $\mathrm{V}_{\text {endo }}(r=0.23, p>0.4)$. That is, with increasing $V_{a}$, endogenous excretion did not increase significantly to compensate for the increased calcium entry into the central compartment.

Because differences in urinary and endogenous fecal calcium excretion accounted for at most a minor change

Table 1. Calcium (Ca) metabolism in $13 \mathrm{VLBW}$ infants *

\begin{tabular}{|c|c|}
\hline Parameter & Value \\
\hline Body weight (kg) & $1.34 \pm 0.03$ \\
\hline Total serum $\mathrm{Ca}(\mathrm{mg} / \mathrm{dL})$ & $9.7 \pm 0.1(2.43 \pm 0.03 \mathrm{mmol} / \mathrm{L})$ \\
\hline $\mathrm{Ca}$ intake $\left(\mathrm{mgkg}^{-1} \cdot \mathrm{d}^{-1}\right)$ & $190 \pm 6\left(4.75 \pm 0.15 \mathrm{mmol} \cdot \mathrm{kg}^{-1} \cdot \mathrm{d}^{-1}\right)$ \\
\hline Percent $\mathrm{Ca}$ absorption & $51 \pm 3$ \\
\hline 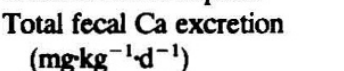 & $119 \pm 9\left(2.97 \pm 0.22 \mathrm{mmol} \cdot \mathrm{kg}^{-1} \cdot \mathrm{d}^{-1}\right)$ \\
\hline$V_{a}\left(m g \cdot k^{-1} \cdot d^{-1}\right)$ & $96 \pm 6\left(2.40 \pm 0.15 \mathrm{mmol} \cdot \mathrm{kg}^{-1} \cdot \mathrm{d}^{-1}\right)$ \\
\hline$V_{\text {endo }}\left(m g k^{-1} d^{-1}\right)$ & $25 \pm 3\left(0.62 \pm 0.08 \mathrm{mmol} \cdot \mathrm{kg}^{-1} \cdot \mathrm{d}^{-1}\right)$ \\
\hline$S_{i}\left(\mathrm{mg}^{\mathrm{kg}}{ }^{-1} \cdot \mathrm{d}^{-1}\right)$ & $71 \pm 7\left(1.78 \pm 0.18 \mathrm{mmol} \cdot \mathrm{kg}^{-1} \cdot \mathrm{d}^{-1}\right)$ \\
\hline$V_{u}\left(m g \cdot k^{-1} \cdot d^{-1}\right)$ & $4.4 \pm 0.5\left(0.11 \pm 0.012 \mathrm{mmol} \cdot \mathrm{kg}^{-1} \cdot \mathrm{d}^{-1}\right)$ \\
\hline$V_{\text {bal }}\left(\mathrm{mgkg}^{-1} \cdot \mathrm{d}^{-1}\right)$ & $66 \pm 7\left(1.65 \pm 0.18 \mathrm{mmol} \cdot \mathrm{kg}^{-1} \cdot \mathrm{d}^{-1}\right)$ \\
\hline Exchangeable pool $(\mathrm{mg} / \mathbf{k g}) \dagger$ & $644 \pm 81\left(16.10 \pm 2.02 \mathrm{mmol} \cdot \mathrm{kg}^{-1} \cdot \mathrm{d}^{-1}\right)$ \\
\hline $\mathrm{Vo}^{+}\left(\mathrm{mg}^{\mathrm{kg}}{ }^{-1} \cdot \mathrm{d}^{-1}\right)$ & $160 \pm 7\left(4.00 \pm 0.18 \mathrm{mmol} \cdot \mathrm{kg}^{-1} \cdot \mathrm{d}^{-1}\right)$ \\
\hline $\begin{array}{l}\text { Bone Ca resorption } \\
\left(\mathrm{mg} \mathrm{kg}^{-1} \cdot \mathrm{d}^{-1}\right)\end{array}$ & $94 \pm 6\left(2.35 \mathrm{mmol} \cdot \mathrm{kg}^{-1} \cdot \mathrm{d}^{-1}\right)$ \\
\hline
\end{tabular}

* All values are mean \pm SEM.

† Exchangeable pool is the sum of compartments 1, 2, and 3 in Figure 1.

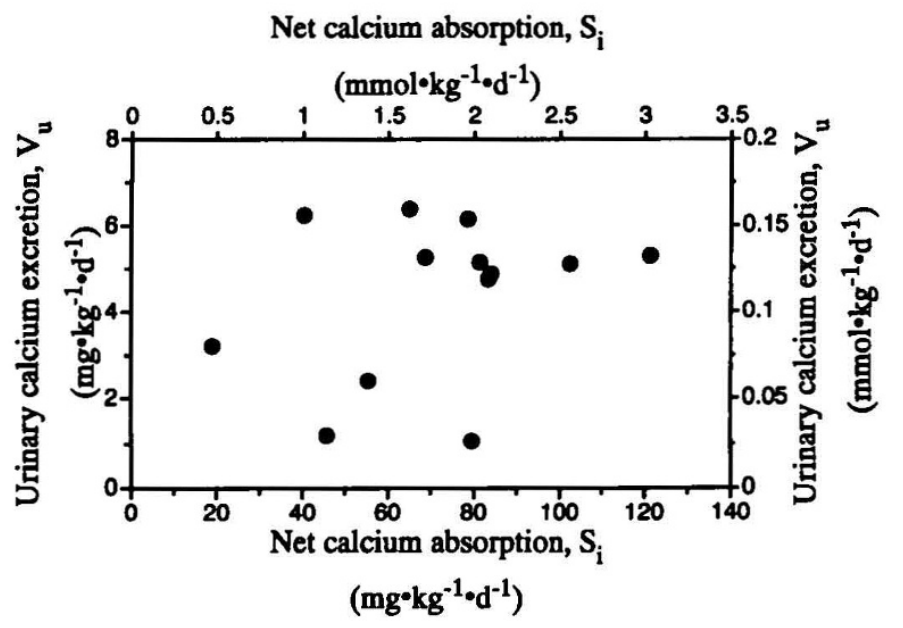

Figure 2. $V_{u}$ in 13 VLBW infants as a function of $S_{i} \cdot V_{u}=3.0+0.02$ $\left(\mathrm{S}_{\mathrm{i}}\right), r=0.29, p=0.33$.

in $S_{i}$, changes in bone calcium deposition or resorption must constitute the principal mode by which variations in $\mathrm{S}_{\mathrm{i}}$ are accommodated.

In our study population, the principal means by which an increase in $S_{i}$ was accommodated was by changes in $\mathrm{Vo}^{+}$. The slope of the relationship between $\mathrm{Vo}^{+}$and $\mathrm{S}_{\mathrm{i}}$, 0.68 , suggests that for each $1-\mathrm{mg}$ increase of calcium input to the system $\left(\mathrm{S}_{\mathrm{i}}\right), 0.68 \mathrm{mg}(0.017 \mathrm{mmol})$ of additional calcium was deposited in bone (Fig. 3). However, bone resorption was also involved in accommodating variations in $S_{i}$; for each increase of $1 \mathrm{mg}$ in $S_{i}$, bone calcium resorption decreased by $0.32 \mathrm{mg}(0.008 \mathrm{mmol})$ (Fig. 4).

Because APA is considered a reflection of bone turnover, it was of interest to relate this widely used clinical parameter to kinetically determined changes in bone calcium deposition, removal, and turnover. There was no significant relationship between APA and $\mathrm{V}_{\mathrm{a}}, \mathrm{S}_{\mathrm{i}}$, or $\mathrm{V}_{\mathrm{bal}}$ $(r<0.2, p>0.4$ for each). Isoenzymes of alkaline phosphatase were not measured. However, in infants, virtually all APA is bone derived and variations in total APA have been closely related to metabolic bone disease in premature infants (21-23).

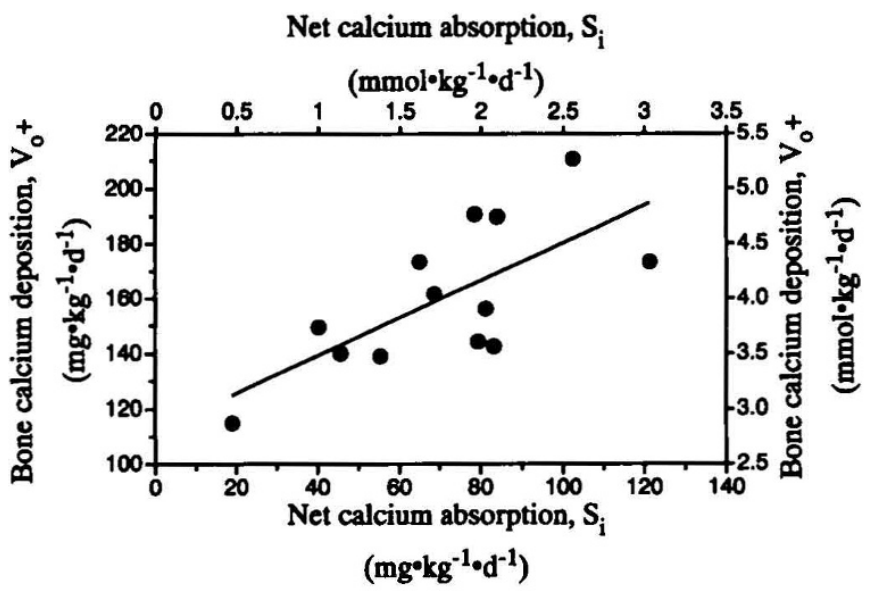

Figure 3. $\mathrm{Vo}^{+}$in $13 \mathrm{VLBW}$ infants as a function of $\mathrm{S}_{\mathrm{i}} \cdot \mathrm{Vo}^{+}=112+$ $0.68\left(S_{i}\right), r=0.70, p<0.01$. 


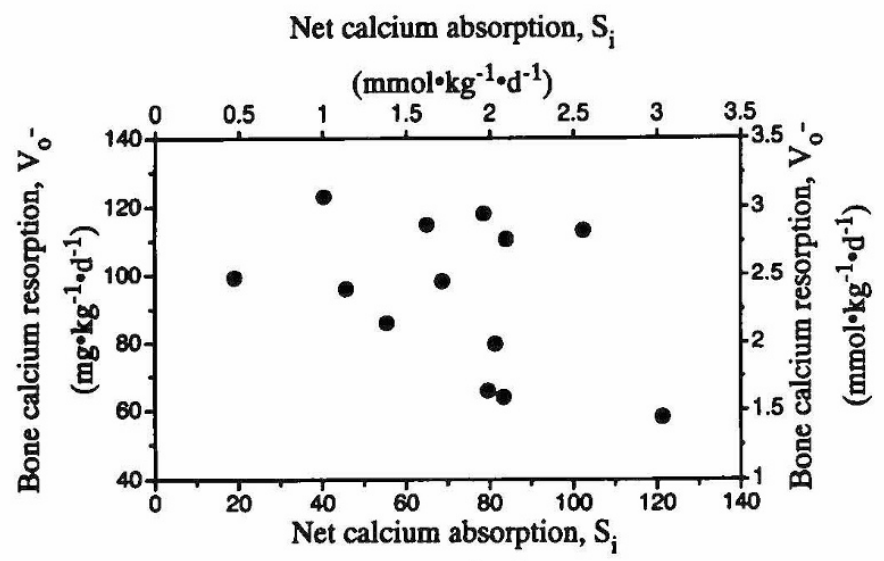

$\left(\mathrm{mg}^{\circ} \mathrm{kg}^{-1} \cdot \mathrm{d}^{-1}\right)$

Figure 4. Bone calcium removal rate $\left(\mathrm{Vo}^{-}\right)$in $13 \mathrm{VLBW}$ infants as a function of $\mathrm{S}_{\mathrm{i}} \cdot \mathrm{Vo}^{-}=117-0.32\left(\mathrm{~S}_{\mathrm{i}}\right), r=-0.39, p=0.18$.

\section{DISCUSSION}

The most striking observation made in this study of how VLBW infants regulate their calcium metabolism was that the major response to a calcium load is by $\mathrm{Vo}^{+}$. Whereas in adults the primary regulatory response to an increase in intestinal calcium absorption is a decrease in bone resorption $(3,5,6,9)$, VLBW infants respond largely by increasing the flow of calcium directed at bone. In both adults and VLBW infants, the effect of these responses is the same, i.e. to maintain the total calcium level of the serum constant.

This difference between adults and VLBW infants may be related to the relatively greater rate at which absorbed calcium is used by the VLBW infant for mineralization of new bone $(13,24,25)$. In older individuals, new bone formation accounts for only a small proportion of bone turnover and probably cannot be increased markedly. Therefore, an increase in absorbed calcium seems to be handled by a decrease in bone resorption (9). This slowing of bone resorption appears to be mediated in part by the release of calcitonin, which occurs in response to the transient increase in plasma calcium $(26,27)$.

Support for this interpretation comes from the study of growing rats $(28,29)$. Male rats raised on a calciumsufficient diet, whose bone mass approaches that of maturity, maintain their plasma calcium constant in the face of an increasing calcium load from the gut by inhibiting bone calcium resorption, whereas bone calcium deposition remains virtually unchanged (29). On the other hand, immature rats, whose bone calcium is still relatively low, increased their bone calcium deposition rate in response to an increased calcium load from the gut (28). In those animals, the slope of the increase in $\mathrm{Vo}^{+}$as a function of $\mathrm{S}_{\mathrm{i}}$ was 0.50 , which is similar to the value of 0.68 observed in this study (Fig. 3).

The average $\mathrm{Vo}^{+}$of $160 \mathrm{mg} \cdot \mathrm{kg}^{-1} \cdot \mathrm{d}^{-1}\left(4 \mathrm{mmol} \cdot \mathrm{kg}^{-1} \cdot \mathrm{d}^{-1}\right)$ in this study (Table 1$)$ exceeds the $\mathrm{Vo}^{+}$for larger $(n=2)$ infants of $129 \mathrm{mg} \cdot \mathrm{kg}^{-1} \cdot \mathrm{d}^{-1}\left(3.22 \mathrm{mmol} \cdot \mathrm{kg}^{-1} \cdot \mathrm{d}^{-1}\right)$ reported by Moore et al. (12) and the mean $\mathrm{Vo}^{+}$of $93 \mathrm{mg} \cdot \mathrm{kg}^{-1} \cdot \mathrm{d}^{-1}$ $\left(2.32 \mathrm{mmol} \cdot \mathrm{kg}^{-1} \cdot \mathrm{d}^{-1}\right)$ reported in three 1 -y-old former premature infants (11). During early puberty, $\mathrm{Vo}^{+}$averaged $55 \mathrm{mg} \cdot \mathrm{kg}^{-1} \cdot \mathrm{d}^{-1}\left(1.37 \mathrm{mmol} \cdot \mathrm{kg}^{-1} \cdot \mathrm{d}^{-1}\right)(18)$, whereas it is generally $8-10 \mathrm{mg} \cdot \mathrm{kg}^{-1} \cdot \mathrm{d}^{-1}\left(0.2-0.25 \mathrm{mmol} \cdot \mathrm{kg}^{-1} \cdot \mathrm{d}^{-1}\right)$ in adults (11). The net $V_{b a l}$ from this study of $66 \pm 7$ $\mathrm{mg} \cdot \mathrm{kg}^{-1} \cdot \mathrm{d}^{-1}\left(1.65 \pm 0.18 \mathrm{mmol} \cdot \mathrm{kg}^{-1} \cdot \mathrm{d}^{-1}\right)$ is similar to that in previous reports using high-mineral-containing diets $(14-16,30,31)$.

The high value of $\mathrm{Vo}^{+}$in VLBW infants is associated with an increase in the relative size of the bone calcium pool. In adults, the exchangeable calcium pool represents about $0.5 \%$ of total body calcium (9). The infants in this study would have approximately $5 \%$ of total body calcium in the exchangeable pool $(11,13,25)$. This is similar to findings in 1-y-old former premature infants (11).

Conceivably, the relatively larger pool of exchangeable calcium in the bone of children reflects a limit on the rate at which calcium can be deposited as bone calcium salt. If such a limit existed, then calcium that enters the pool at rates exceeding the rate of calcium salt deposition would expand the pool of calcium in solution $(32,33)$. This possibility cannot be excluded, but available evidence makes it unlikely that the rate of crystal formation is significantly slower than the rate of calcium entry into the bone (34-36). Moreover, it has recently been shown (18) that the better-hydrated bone of prepubertal girls has a lower $\mathrm{Vo}^{+}$than the less-hydrated bone of older, pubertal girls. This suggests that hydration level does not account for the increases in pool sizes and $\mathrm{Vo}^{+}$seen during puberty (18).

The failure of the APA to vary with either $\mathrm{Vo}^{+}$or bone calcium removal may in part be due to the nonspecificity of the total APA measurement, although most of the APA in infants is bone derived (21). This is not true of older children (aged 5-15 y), in whom a relationship between kinetically determined bone turnover and APA has been found (Abrams SA, unpublished observations). Our findings are consistent with the previously reported minimal correlation that exists between APA activity and calcium balance or bone density $(15,22)$. A larger sample size of premature infants would be needed to further evaluate these relationships. It is likely that only severe mineralization deficits lead to a significant rise in the alkaline phosphatase activity $(22,23)$ and that such deficits did not occur in our study population, even among those infants with relatively low $S_{i}$ values.

In summary, our findings are consistent with the interpretation that the third trimester in utero period represents a maximum period of bone calcium deposition. How mineral deficiency would alter calcium metabolism during this period is not known, nor is it known by what mechanism bone mineralization catches up in mineraldeficient premature infants after their discharge from the hospital. Until these processes are better understood, it seems prudent to supply VLBW infants with enough dietary calcium to support new bone formation and the bone turnover needed for growth. 
Acknowledgments. The authors thank Pamela Burns, R.N., and the nursing staff of the Neonatal Clinical Research Unit at Texas Children's Hospital; Jun Zhu, Lily Liang, and Charles Imo for technical assistance; E.O. Smith, Ph.D., for biostatistical support; and Leslie Loddeke for editorial assistance.

\section{REFERENCES}

1. Neer R, Berman M, Fisher F, Rosenberg LE 1967 Multicompartmental analysis of calcium kinetics in normal adult males. J Clin Invest 46:1364-1378

2. Bronner F 1964 Dynamics and function of calcium. In: Comar CL, Bronner F (eds) Mineral Metabolism: An Advanced Treatise, Vol II. The Elements, Part A. Academic Press, New York, pp 341-444

3. Aubert JP, Bronner F, Richelle LJ 1963 Quantitation of calcium metabolism. Theory. J Clin Invest 42:885-897

4. Aubert JP, Milhaud G 1960 Méthode de mesure des principales voies du métabolisme calcique chez l'homme. Biochem Biophys Acta 39:112-139

5. Bronner F 1973 Kinetic and cybernetic analysis of calcium metabolism. In: Irving JT (ed) Calcium and Phosphorus. Academic Press, New York, pp 149-186

6. Bronner F, Lemaire R 1969 Comparison of calcium kinetics in man and the rat. Calcif Tissue Res 3:238-248

7. Heaney RP 1976 Calcium kinetics in plasma as they apply to the measurements of bone formation and resorption rates. In: Bourne GH (ed) The Biochemistry and Physiology of Bone, 2nd Ed, Vol IV, Calcification and Physiology. Academic Press, New York, pp 106-133

8. Aubert JP, Bronner F 1965 A symbolic model for the regulation by bone metabolism of the blood calcium level in rats. Biophys $\mathrm{J}$ 5:349-358

9. Bronner F 1982 Calcium homeostasis. In: Bronner F, Coburn JW (eds) Disorders of Mineral Metabolism. Academic Press, New York, pp 43-102

10. Hansen J, Gordan G, Prussin S 1973 Direct measurement of osteolysis in man. J Clin Invest 52:304-315

11. Abrams SA, Esteban NV, Vieira NE, Sidbury JB, Specker BL, Yergey AL 1992 Developmental changes in calcium kinetics in children assessed using stable isotopes. J Bone Miner Res 7:287-293

12. Moore LJ, Machlan LA, Lim MO, Yergey AL, Hansen JW 1985 Dynamics of calcium metabolism in infancy and childhood. I. Methodology and quantification in the infant. Pediatr Res 19:329-334

13. Ziegler EE, O'Donnell AM, Neison SE, Fomon SJ 1976 Body composition of the reference fetus. Growth 40:329-341

14. Abrams SA, Esteban NV, Vieira NE, Yergey AL 1991 Dual tracer stable isotopic assessment of calcium absorption and endogenous fecal excretion in low birth weight infants. Pediatr Res 29:615-618

15. Schanler RJ, Abrams SA, Garza C 1988 Bioavailability of calcium and phosphorus in human milk fortifiers and formula for very low birth weight infants. J Pediatr 113:95-100

16. Abrams SA, Yergey AL, Schanler RJ, Vieira NE, Welch TR 1994 Hypercalciuria in premature infants receiving high mineral-containing diets. $J$ Pediatr Gastroenterol Nutr 18:20-24
17. Yergey AL, Abrams SA, Vieira NE, Hillman AL, Covell DG 1990 Recent studies of human calcium metabolism using stable isotopic tracers. Can J Physiol Pharmacol 68:973-976

18. Abrams SA 1993 Pubertal changes in calcium kinetics in girls assessed using ${ }^{42}$ Ca. Pediatr Res 34:455-459

19. Bronner F 1962 Experimental studies of calcium absorption in man. Nutritio et dieta $3: 22-31$

20. Heaney RP, Skillman TG 1964 Secretion and excretion of calcium by the human gastrointestinal tract. J Lab Clin Med 64:29-41

21. Cao A, Coppa G, Trabalza N, Marcucci F, de Virgillis S, Lungarotti S, Furbetta M 1972 Characterization of serum alkaline phosphatase in infancy and childhood. Z Kinderheilk 113:289-296

22. Abrams SA, Schanler RJ, Garza C 1988 Relation of bone mineralization measures to serum biochemical parameters. [letter] Am J Dis Child 142:1276

23. Walters EG, Murphy JF, Henry P, Gray OP, Elder GH 1986 Plasma alkaline phosphatase activity and its relation to rickets in pre-term infants. Ann Clin Biochem 23:652-656

24. Abrams SA, Schanler RJ, Tsang RC, Garza C 1989 Bone mineralization in former very low birth weight infants fed either human milk or commercial formula: one-year follow-up. J Pediatr 114:1041-1044

25. Widdowson EM, Dickerson JWT 1964 Chemical composition of the body. In: Comar CL, Bronner F (eds) Mineral Metabolism: An Advanced Treatise, Vol II, The Elements, Part A. Academic Press, New York, pp 1-247

26. Talmage RV, Doppelt SH, Cooper CW 1975 Relationships of blood concentrations of calcium, phosphate, gastrin and calcitonin to the onset of feeding in the rat. Proc Soc Exp Biol Med 149:855-859

27. Bronner F, Stein WD 1992 Modulation of bone calcium-binding sites regulates plasma calcium: an hypothesis. Calcif Tissue Int 50:483-489

28. Hurwitz S, Stacey RE, Bronner F 1969 Role of vitamin D in plasma calcium regulation. Am J Physiol 216:254-262

29. Sammon PJ, Stacey RE, Bronner F 1970 Role of parathyroid hormone in calcium homeostasis and metabolism. Am J Physiol 218:479-485

30. Bronner F, Salle BL, Putet G, Rigo J, Senterre J 1992 Net calcium absorption in premature infants: results of 103 metabolic balance studies. Am J Clin Nutr 56:1037-1044

31. Hillman LS, Johnson LS, Lee DZ, Vieira NE, Yergey AL 1993 Measurement of true absorption, endogenous fecal excretion, urinary excretion, and retention of calcium in term infants by using a dual-tracer stable-isotope method. J Pediatr 123:444-456

32. Burkinshaw L, Marshall DH, Oxby CB, Spiers FW, Nordin BEC, Young MM 1969 Bone turnover model based on a continuously expanding exchangeable calcium pool. Nature 22:146-148

33. Jung A, Bartholdi P, Mermillod B, Reeve J, Neer R 1978 Critical analysis of methods for analyzing human calcium kinetics. J Theor Biol 73:131-157

34. Bauer GCH 1954 The importance of bone growth as a factor in the redistribution of bone salt. II. Redistribution of radioactive phosphorus in the skeleton of rats. J Bone Joint Surg 36:381-387

35. Simmons DJ, Grynpas MD 1990 Mechanisms of bone formation in vivo. In: Hall BK (ed) Bone: Vol 1. The Osteoclast and Osteocyte, Telford Press, Caldwell, NJ, pp 193-302

36. Nancollas SH, Zavacki SJ 1989 Calcium phosphate mineralization. Connect Tissue Res 21:239-246 